\title{
The Influence of Learning Strategy (Contextual and Expository) and Musical Intelligence in Melodi on Learning Result of Harmoni I
}

\author{
Uyuni Widiastuti \\ Departement of Music Education \\ Universitas Negeri Medan \\ Medan, Indonesia \\ Corresponding Email : yuniyhundai@gmail.com \\ Harun Sitompul \\ Departement of Educational Technology \\ Universitas Negeri Medan \\ Medan, Indonesia \\ Abdul Muin Sibuea \\ Departement of Educational Technology \\ Universitas Negeri Medan \\ Medan, Indonesia
}

\begin{abstract}
Learning strategy is used by an educator in delivering the material to achieve the learning objectives. Musical intelligence includes a person's ability to be sensitive to nonverbal voices. The purpose of this research is to know the difference of learning result of Harmony I course between group of students which is taught by contextual learning strategy with group of students which is taught by expository learning strategy. This research uses quasi experimental research with $2 \times 1$ factorial design. The result of the research with ANOVA calculation on $\alpha \mathbf{0 , 0 5}$ stated that the result of Harmony I study group of students with musical intelligence in melody that is taught by contextual learning strategy is higher than student group with musical intelligence in melody which is taught by an expository learning strategy. There is no interaction effect between learning strategy and musical intelligence on Harmony I learning outcomes. The conclusion is that there is no difference in Harmony I learning outcomes that are taught by contextual learning strategy and expository learning strategy in students with musical intelligence in melody.
\end{abstract}

Keywords-component; Learning Strategy, Musical Intelligence in Melody, Harmony I.

\section{INTRODUCTION}

Art education has a meaning as a gift of aesthetic experience to learners that is done through appreciation and creation in which contain value of expression as a form of meaningful expression. Aesthetic experience is impossible to achieve without involving the taste (emotion, aesthetics), if the heart (work, ethics), creative (thinking, logic) and sports (physical, kinesthetic).

Intelligence is a ability or skill that can be grown. Each individual has an inherent intelligence in each of the different stages of development, the intelligence is called Multiple intelligences, one of which is musical intelligence. It is also reinforced by Uno's ${ }^{[1]}$ argument that individuals are easier to remember and express ideas when associated with musical.

Harmony I course is one of the courses in the major of Music Education in the third semester. The purpose of Harmony I courses is as a basis in arranging or changing a song into 4 voices of soprano, alto, tenor and bass. So far it is known that the results of Harmony I study subjects are not satisfactory, this is caused by several factors, such as the lack of understanding of students in the subject of Music Theory, learning strategies used by lecturers is not appropriate and the less used piano and vocal as a medium of learning.

From the above explanation can be expressed through the research of how the influence of learning strategies (contextual and expository) and musical intelligence in melody against the results of learning Harmony I, so the purpose of this study is to determine the difference of learning outcomes Harmony I courses between groups of students who is taught with strategy contextual learning with groups of students who are taught with expository learning strategies with musical intelligence in melody.

Learning strategy is the planning and implementation used by an educator to deliver the material by following the steps that have been determined in order to achieve the expected learning objectives. Learning strategy is a combination of sequence of activities, ways of organizing learning materials and students, equipment, and materials and time spent in the learning process to achieve the learning objectives that have been determined Suparman ${ }^{[2]}$. Learning strategy helps learners to receive learning materials and help educators to provide learning materials. 
Contextual learning strategy (CTL) is a learning concept that helps teachers relate between the material taught to the real-world situations of the students and encourages students to make connections between their knowledge and application in their daily lives by involving seven components: constructivism, inquiry, community learning, modeling, reflection, authentic assessment Trianto ${ }^{[3]}$. Kunandar ${ }^{[4]}$ stated that contextual learning is a learning concept assuming that children will learn better if the environment is created naturally, meaning that learning will be more meaningful if the child is working and experiencing what he or she has learned, not just knowing it. This is reinforced by Suparman's findings ${ }^{[5]}$ which suggests that students who are taught with contextual learning can significantly achieve better than conventional learning.

Direct instructional is identical to expository, direct learning requires clear actions and decisions from the teacher during the planning at the time of the learning and time assessment.

Expository learning is identical to direct instructional model or direct instruction or better known as direct instruction. Direct teaching is a learning that is teacher learning centered, while according to Joice ${ }^{[6]}$, there are two goals of direct learning that is maximizing student learning time and develop self-reliance in achieving and realizing educational goals.

Musical intelligence includes a person's ability to be sensitive to the non-verbal sounds that surround him, including in this case the tone and rhythm. Musical intelligence involves self-regulation and the structure of thinking, which is not necessarily related to other types of intelligence Linda Campbell ${ }^{[7]}$. This is also reinforced by Sumaryanto's research ${ }^{[8]}$ which suggests that the achievement of music can be influenced by musicality that can be developed through directional and regular practice. Mudjilah research ${ }^{[9]}$ suggests a child's musical ability can be seen from three dimensions of distinguishing tones, imitating melodies and responding to rhythms. Research Susan W Mills $^{[10]}$ argues that the school climate is very influential in determining the role of musical intelligence.

\section{RESEARCH METHODOLOGY}

This study was classified into quasi experimental research (quasi experiments), with the following research designs: In the treatment design of this study using $2 \times 1$ factorial design which contained a different independent variable (contextual and expository) and one moderator variable (musical intelligence melody), the dependent variable in this study is the result of learning Harmoni I

The hypothesis test ${ }^{[11]}$ was performed by variance analysis (ANAVA) with factorial design $2 \times 1$. Further test was performed by using the Tukey test ${ }^{[12]}$. Prior to hypothesis testing the first test of the analysis requirements was divided: normality test, homogeneity test, regression linearity test [13], significance test of regression effect and (5) line alignment test $^{[14]}$.

\section{DISCUSSION}

A. Description of Learning Data Result

1. Description of learning result data of Harmony I students with musical intelligence melody that is taught by contextual learning strategy.

The result data of Harmony I students with musical intelligence melody taught with contextual learning strategy is known to mean $=83,50 ;$ mode $=90.04 ;$ Median $=85.94$; Variance $=122,84 ;$ Standard deviation $=11.08 ;$ Maximum score $=100 ;$ and minimum score $=60$.

2. Description of learning data of Harmony I students with musical intelligence melody that is taught by expository learning strategy.

Data of Harmony I study result of students with musical intelligence of melodies taught with expository learning strategy known mean $=73,73 ;$ mode $=84,17$; median $=73,37$; variance $=160,76 ;$ standard deviation $=12.68$; Highest score $=94 ;$ and the lowest score $=52$.

\section{B. Testing Requirements}

1. Normality Testing

Test normality of learning result of Harmony I student with musical intelligence melody which is taught by contextual learning strategy obtained Liliefors value of equal to 0,1109 while value of Liliefors table with $\mathrm{N}=42 \alpha=0,05$ which is 0,1367 . Thus it is known that the value of Liliefors count is smaller than the value of Liliefors table that is 0.1109 $<0.1367$ then it is concluded that the data of Harmony I study results students with musical intelligence melody taught with contextual contextual learning strategies.

Test normality of learning result of Harmony I student with musical intelligence melody which is taught by expository learning strategy obtained Liliefors value counted 0.0772 while Liliefors table value with $\mathrm{N}=37 \alpha=0,05$ which is 0,1457 . Thus it is known that the value of Liliefors count is smaller than the value of Liliefors table that is $0.0772<0.1457$ it is concluded that the results of learning Harmony I students with musical intelligence melodies are taught with expository learning strategies are normally distributed.

\section{Homogeneity Test}

Homogeneity test of study result data group Harmony I students with musical intelligence melody taught by contextual learning strategy with expository learning strategy obtained value obtained price Fcount $=1,31$ while price $\mathrm{F}$ table at $\alpha=0,05, \mathrm{dk}$ numerator $=41$ and $\mathrm{dk}$ numerator $=36$ that is 1.71. Based on these data it can be seen that the price of Fcount < Ftable. Thus it can be concluded that the results of learning Harmony I students with musical intelligence melodies are taught with contextual learning strategies and expository learning strategies derived from homogeneous variations. 


\section{Hypothesis Testing}

Based on the result of variance analysis test, it can be explained that hypothesis testing result of learning Harmony I student which is taught by contextual learning strategy is higher than the result of learning Harmony I student who is taught by expository learning strategy.

Based on the calculation of ANAVA as stated in the table above shows the price $\mathrm{F}$ count $=12.49$ whereas the value $\mathrm{F}$ table $=3.966$ at $\alpha=0,05$. It turns out that $F$ count $>F$ table is thus hypothesis testing reject Ho so accept $\mathrm{Ha}$ in other words research hypothesis proposed accepted the result of learning Harmony I students who is taught with contextual learning strategy is higher than the results of learning Harmony I students are taught with expository learning strategies. Furthermore the acquisition of the average value of learning outcomes Harmony group of students with musical intelligence melody is taught with contextual learning strategies $\mathrm{A} 1=83.50$ and groups of students with musical intelligence melody is taught with expository learning strategy A2 $=73.73$.

\section{Research Findings}

The findings in this study say that contextual learning strategy can improve Harmony I learning outcomes compared with expository learning strategy, so that this finding also answer the research hypothesis that the result of learning Harmony I students with musical intelligence melody that is taught by contextual learning strategy better than student learning result with musical intelligence melodies being taught with an expository learning strategy.

Furthermore, because the results of hypothesis testing main effect Ho rejected, then $\mathrm{H} 1$ accepted then tested further to see the effect of interaction between learning strategies with musical intelligence melody. The calculation results show that the price of Fcount $=3.69$ is smaller than the price Ftable 3.966 at $\alpha 0.05$, it is meaningful to accept Ho and reject $\mathrm{H} 1$. Thus it can be concluded that there is no difference in learning outcomes Harmony I taught with contextual learning strategies and expository learning strategies in students with musical intelligence melody.

Furthermore, based on descriptive analysis, although the average result of learning outcomes Harmony I group of students with musical intelligence melody taught by contextual learning strategy $\mathrm{A} 1 \mathrm{~B}=83.50$ higher than the average value of learning outcomes Harmony I group of students with musical intelligence melody which is taught by $\mathrm{A} 2 \mathrm{~B}$ exposure learning strategy $=73.73$. However, the results of statistical tests continued to show the difference is not meaningful, in other words the results of learning Harmony I students with musical intelligence melodies are taught with contextual and expository learning strategies are not much different. This indicates that for students with musical intelligence the melody has the result of learning Harmony I students who are not much different or the same between students who are taught with contextual learning strategy and expository learning strategy.

\section{CONCLUSION}

The conclusions in this discussion are: Harmony I learning outcomes group of students with musical intelligence melodies taught by contextual learning strategy is higher than the group of students with musical intelligence melodies are taught with expository learning strategies. This is evidenced based on the results of ANOVA calculations that show the value of Fcount $=12.49$ while the value Ftable $=3.966$ at $\alpha 0,05$. Average learning outcomes Harmony I student group with musical intelligence melody taught with contextual learning strategy $=$ 83,50. Average Harmony I learning outcomes of students with musical intelligence melodies are taught with expository learning strategies $=73.73$. There is no interaction effect between learning strategy and musical intelligence on Harmony I study result. It is proved based on the result of further test calculation shows the price Fcount $=3.69$ is smaller than the price Ftable 3,966 at $\alpha 0,05$, it is meaning to accept Ho and refuse H1. Thus it can be concluded that there is no difference in learning outcomes Harmony I taught with contextual learning strategies and expository learning strategies in students with musical intelligence melody.

\section{REFERENCES}

[1] Uno, B Hamzah. 2009. Mengelola Kecerdasan dalam Pembelajaran Sebuah Konsep Pembelajaran Berbasis Kecerdasan, Jakarta: Bumi Aksara, pp.12.

[2] Suparman, Atwi.2001. Desain Instruksional, Jakarta: UT, pp. 167.

[3] Trianto, 2010. Mendesain Model Pembelajaran inovatif- Progresif, Jakarta: Kencana, pp. 107

[4] Kunandar, 2007. Guru Professional, Jakarta: Rajawali Press, pp. 295

[5] Suparman, Lalu, 2013. The Effect of Contextual Teaching and Learning Approach and Achievement Motivation Upon Student's Writing Competency for the Tenth Grade students of SMA Negeri 1 Keruak in the Academic Year 2012-2013. E-journal. Bali: PPs Universitas Pendidikan Ganesha.

[6] Joice, Bruce, etc, Bruce. 2011. Models of Teaching, Newyork: USA Pearson Education, Inc. Publishing as Allyn \&Bacon, One lake Street Uppet Saddle River, pp. 368.

[7] Linda Campbell, etc. 1996. Teaching \& Learning Through Multiple Intelegences, USA: Schuster Company. pp. 133.

[8] Sumaryanto, Totok. 2000. Kemampuan Musical (Musical Ability) dan Pengaruhnya Terhadap Prestasi Belajar Musikal, Semarang: Jurnal Harmonia, Vol.1 No.1/Mei-Agustus, 2000.

[9] Mudjilah Hanna Sri, 2014. Pengembangan Tes Kemampuan Musikal Anak, Dissertation; Universitas Negeri Yogyakarta, pp.86.

[10] Mills, W Susan, The Role of Musical Intelligence in a Multiple intelligence Focused Elemntary School, ( International Journal of education and the Arts. 2 (4). )Sep 2001) (ISSN: 1529-8094) copy of record can be obtained. http://www.ijea.org/v2n4/index.html, 2001.

[11] Kadir. 2015. Statistika Terapan : Konsep, Contoh, dan Analisis Data dengan Program SPSS/Lisrel dalam Penelitian. Jakarta : Rajawali Pers.

[12] Glass, R.V., Hopkins, K.D. 1984. Statistical Methods in Education and Psychology $2^{\text {nd }}$ Edition. New Jersey: Prentice-Hall, Inc., pp. 371.

[13] Sudjana. 2005. Metode Statistika. Bandung : Tarsito, pp.330-337.

[14] Agung, IG. N. 2006. Statistika Penerapan Model Rerata-Sel Multivaria dan Model Ekonometrika dengan SPSS. Jakarta: Yayasan Sad Satria Bhakti, pp. 284. 